\title{
The Formation and Organization of Self-Assembled Monolayer (SAM) for Escherichia coli Detection: A Review
}

\author{
Atqiya Muslihati, Hatijah Basri, Mohd. Zainizan Sahdan, Kusnanto Mukti Wibowo, \\ Nurliyana Rosni, Marlia Morsin \\ \{ atqiyamus313@gmail.com ${ }^{1}$, hatijah@uthm.edu.my ${ }^{2}$, zainizan@uthm.edu.my ${ }^{3}$, \\ kusnantomukti@gmail.com ${ }^{4}$, liyanarosni123@gmail.com ${ }^{5}$, marlia@uthm.edu.my ${ }^{6}$ \}
}

Faculty of Applied Science and Technology, UTHM, Johor, Malaysia ${ }^{1,2}$, Microelectronics and Nanotechnology Shamsuddin Research Centre (MiNT-SRC), UTHM, Johor, Malaysia ${ }^{1,3,4,5,6}$

\begin{abstract}
SAM is known as a tuneable platform through an ultra-thin, biocompatible, and controlled organic film formed by self-assembled from a strong chemisorption of thiols (R-S-H) or its derivatives (R-OH, R-COO, R-COOH, R-NH2, etc.) onto metal or semiconductor substrate. The monolayer is offering hydrophobic-hydrophilic control depending on their terminal group. These flexibilities were functionalized in order to immobilize the biomolecule like DNA/RNA, antibody/antigen, bacteriophages, and aptamers as a selective receptor to capture E. coli selectively as the most dangerous microorganism in environmental water into an array system called biosensor. A number of methods have been developed to characterize the performance of SAM functionalization in immobilizing biomolecule for E. coli rapid detection and real time in optical and electrochemical (amperometric, potentiometric, and impedimetric). Till date, nano-materials and nanotechnologies has significantly contributed as a key role as in basic platform forming the sensor sensitively. Nano materials offer attractive properties like shape dependent physical and unique size, easy synthesize, easy surface functionalization, and enhancement of an electron transfer. This review will discuss the biomolecule immobilization techniques with SAM and the sensing mechanism.
\end{abstract}

Keywords: Self-assembled monolayers; E. coli; Biosensor; Nanomaterial

\section{Introduction}

Escherichia coli (E. coli) bacteria normally live in the human and animal intestines. Most E. coli are harmless and actually are an important part of a healthy human intestinal tract. However, some E. coli are pathogenic, meaning they can cause illness, either diarrhea or illness outside of the intestinal tract like bloodstream, urinary system, and central nervous system. The type of $E$. coli that can cause diarrhea can be transmitted through contaminated water or food, or through contact with animals or persons [1]-[3].

E. coli is a dangerous microorganism till date urgently need to be controlled due to has been more spreading out drastically. The disease reported up to May 2017 by The Association of World Health Organization is 1.7 billion people in the world died because of contaminated water containing E. coli [4]. Urgently, the presence and concentration should be monitored. 
Conventional method is the most common method to measure the bacteria concentration in environment called plate count due to the laboratory's method in agar plate. However, the conventional method demonstrated is time consuming and complicated [5]-[9]. It requires to skilled technician and long-time incubation with minimum 48 hours. Additionally, ex situ detection is sensitive to contaminant during the movement from the habitat to the laboratory affecting to bias result. To accomplish it a biosensor device have been developed, while selectivity become a serious issue to be solved. Absolutely biomolecules as a promising agent has been explored to be immobilized as a bioreceptor that can transfer the signal to a transducer [10].

A novel self-assembled monolayer from thiols offer in a nanometer thickness organic film as the novel substrates for biological system [11]-[13]. Its terminal functionality can be used to enhance nonspecific target adsorption providing desired scaffold with the terminal function variation, while its compatibility and stability with metal provide measurement of current and potential for electrochemical properties as substrate, sensing layer or even an electrode that lead to semiconductor agent [14][15]. Moreover, an ordered wettability (hydrophobic \& hydrophilic), distance, corrosion, friction, oxidation are able to control depending on the functionalization of the layer [16][17].

\section{Escherichia Coli}

\subsection{Classification and structure of E. coli)}

Escherichia coli is characterized as an enterobacteria; mostly motile gram negative, rod shaped, and facultative anaerobic which live in the gastrointestinal of normal human and animal as a warm blood (Fig.1A). E. coli consists of a diverse group of bacteria. Pathogenic $E$. coli strains are categorized into pathotypes. Six pathotypes are associated with diarrhea and collectively are referred to diarrheagenic E. coli. There are Enterotoxigenic E. coli (ETEC), Enteropathogenic E. coli (EPEC), Enteroaggregative E. coli (EAEC), Enteroinvasive E. coli (EIEC), Diffusely adherent E. coli (DAEC), and Shiga toxin producing E. coli (STEC), that may also referred to Enterohaemorrhagic (EHEC) as the most commonly known in association with foodborne breaks [21][22].

Exopolysaccharide plays an important role due to in bacterial pathogenicity and the microbial population ecology just like colonization, residence, and adaptation mechanism in various ecosystem. LPS contains of three different domains, there are lipid A, the core oligosaccharide, and the outer domain is the O-lipopolysaccharide, a hydrophilic and immunodominant. About 20 different sugar molecules may compose the $\mathrm{O}$ antigen, including molecules that are often found in nature, such as abequose, colitose, paratose and tyvelose (Fig.1B). These components are strain-specific. The $\mathrm{O}$ antigen displays a large degree of interspecies and intra-species variation, which is related to the nature, order and union of the different sugars. Therefore, O-antigen is the right target of the host due to the serological classification every serotype of negative gram bacteria. The $\mathrm{O}$-antigen will be attached by the anti $\mathrm{O}$-antigen as innate immune response. The synthesis of $\mathrm{O}$-antigen is coded by $\mathrm{rfb}$ gene that is on duty with the biosynthesis of the nucleotide sugars of antigen $\mathrm{O}$, the transfer of the sugars to form the polysaccharide chain (glycosyltransferases) and the assembly and transfer of antigen O toward the periplasm (Fig.1C) [19][20]. 


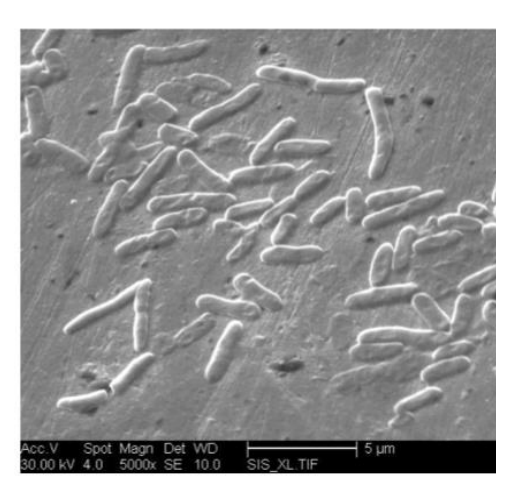

(A)

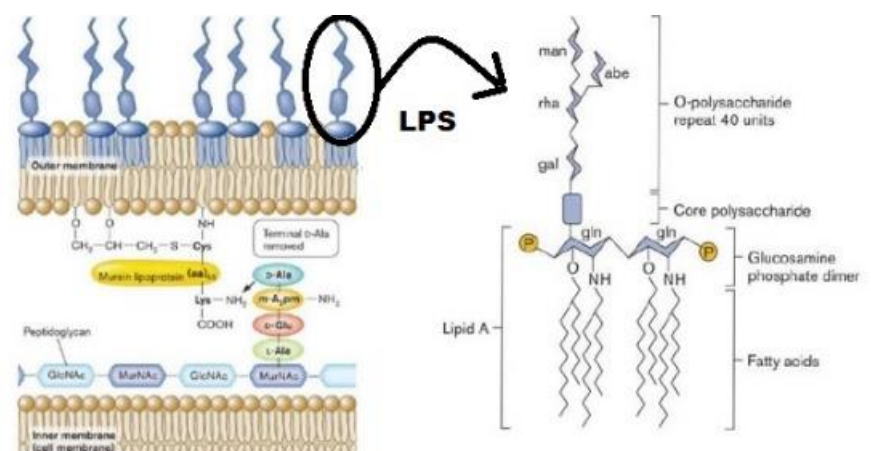

(B)

E. coli 055:H7 NC_013941.1

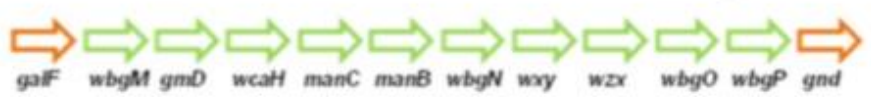

(C)

Fig. 1. (A) Escherichia coli bacteria attached on a gold electrode in SEM characterization [18], (B) Cross section of negative gram bacteria outer membrane and the structure of LPS [19], and (C) genes location involved to synthesis of O-antigen for E. coli O55:H7 [20].

\subsection{E. coli physiology}

Bacteria metabolism are closed to the present of enzyme. Purified enzyme ubiquitously then functionalized as biological sensing material metabolizing specific chemical compounds in a wide range. Due to in remain active enzyme and stable compound, it survives in multicondition and detect variative molecules [23]. However, firstly discovered that E. coli produce GUD as enzyme catalysing the hydrolysis of $\beta$-D-glucopyranosiduronic. Many chromogenic and fluorogenic substrates exist for the specific detection of bacterial enzymatic activities and various commercial tests based on these substrates are available [24]. Another specialization of E. coli is also potentially functionalized. E. coli are also being the suitable host for the specific bacteriophage. The infection initiates the viral binding step onto the host cell surface [25].

\section{Self-assembled Monolayer (SAM)}

\subsection{Structure of SAM}

Briefly, SAMs are desired molecular assembly structured by the naturally adsorption on a solid surface by an active surfactant allowed from a solution or gas phase. However, surfactant is composed of an active head group surface, a spacer group which generally are alkyl group, and a tail group. In the equilibrium approaches system, the interfaces chemical reaction produces these dimensional systems from the assembly. Absolutely, the length of alkyl chain plays an important role in determining degree of desired molecular assembly [23]. 
The various function can be formed with variating some different length alkyl chain and the tail as the terminal group, existence of oligo ethylene glycol, and the formation of thiol and disulphide. Broadly known that both thiol and disulphide derivatives are able to form SAM. It is well thought that thiol forms Au-S bond and produce hydrogen. Although there is no report development experiment show that hydrogen was detected. Disulphide derivatives are lower in solubility than thiol derivative, hence thiol is used more in some applications [23].

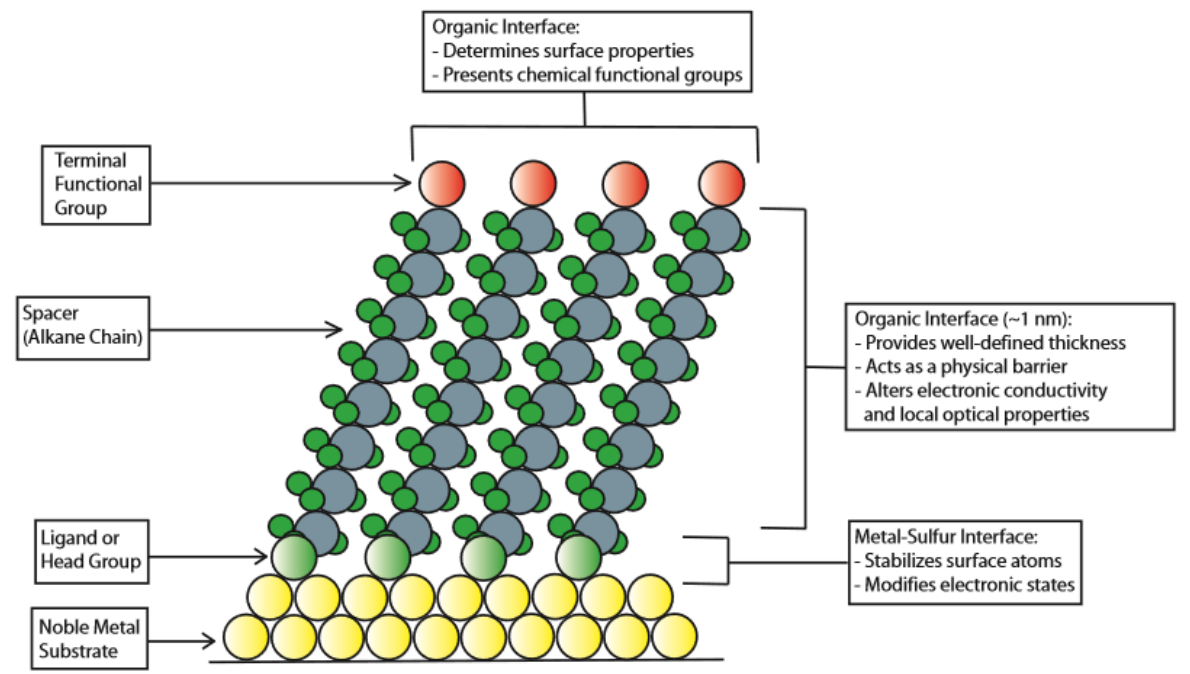

Fig. 2.. A single-crystalline of alkanethiol SAM schematic diagram [23]

By the theory described, generally SAM is known as an organic film in a nanometer thickness by a strong alkanethiols and its derivative chemisorption on a solid surface selfassembled that was introduced firstly by Nuzzo and Lara in 80s [24]. The film provides high orientation degree, packing as order. The crystallinity of SAM is due to a sulphur group attached on substrate such as some selected metallic or any semiconductor surface [25], spacer group called tail obtained from controlled alkyl group $\left((\mathrm{CH})_{n}\right)$, and a head group with any desired chemical group to provide an ordered platform towards surface functionalization (Fig.2) [26].

Some definitions of SAM are being discussed in different terminologies:

1. SAM is formed in a chemical solution, and the formed film is from the random molecules motion and the affinity binding sites for one to other. It also means to the complementary surfaces joining by the interactions of nano-molecular.

2. SAM is an integration method which the structure spontaneously assembles, easily by mixing an ordered chemical around in solution or a phase of gas until reaching the stable state of minimum energy.

3. SAM is a process series which one change a non-living chemical system become a living.

These three highlight terminologies are problems to define self-assembly due to its highly developed and interesting topics in science area. Some applications of SAM are spreading expanded, such as in implant dentistry, medical, and sensor as the most. 


\subsection{Formation of SAM}

However, SAM's formation starts spontaneously with hydrophilic chemisorption of terminal sulphur group by driving force of sulphur bond affinity onto substrate forming a stable and semi covalent bond. This driving is followed by hydrophobic and Van der Walls interactions between the methylene carbons on the alkane chain [26]. The adsorbate will lie down to a phase before developing a parallel phase and change to standing-up phase. The last phase is re-arrangement to produce a systematic layer both in crystalline or semi-crystalline, until the growing is going on and cover all the surface area (Fig.3) [27].

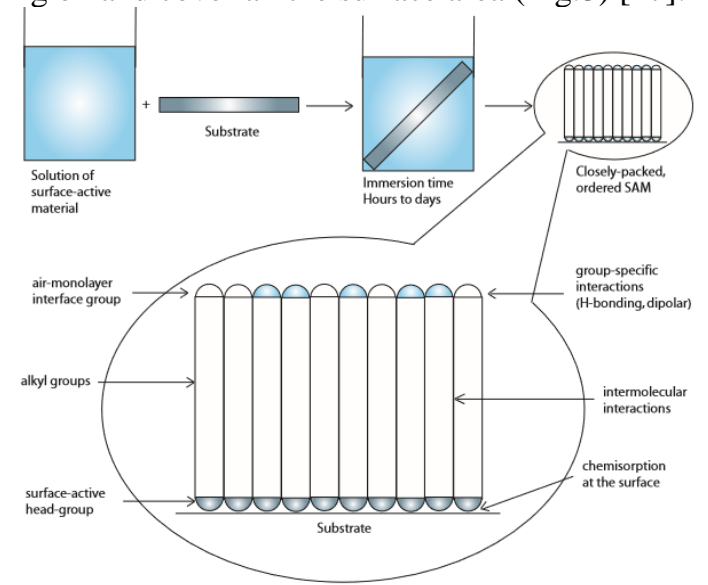

Fig. 3. SAM formation by immerse method into a solution of an active surface substrate [23]

Nowadays, nanomaterials offer easy synthesis, sensitive, easy functionalization, and exhibit electrical properties. These nanomaterials are from metal ( $\mathrm{Au}, \mathrm{Ag}, \mathrm{Cu}, \mathrm{Al}$, and $\mathrm{Ti}$ ), oxidized $\left(\mathrm{AlO}_{2}, \mathrm{TiO}_{2}\right.$, and $\left.\mathrm{SiO}_{2}\right)$, or semiconductor $(\mathrm{Si})$ [28][29]. It is broadly known that gold $(\mathrm{Au})$ is the inert substrate mostly used for SAM because sulphur has a high affinity for gold [30]. It offers smooth and stable surface, free from oxide contamination in a potential range by cycling +0.5 and $-1.4 \mathrm{~V}$ vs. SCE in electrolytes like $0.5 \mathrm{M} \mathrm{H}_{2} \mathrm{SO}_{4}$ [31]. Although $\mathrm{Au}$ has been the promised substrate with its stability, foregoing research demonstrated that another gold could be SAM's substrate in fabricating E. coli sensor (Table 1).

Table 1. SAM approach in different substrate

\section{SAM approach}

\begin{tabular}{|c|c|}
\hline SAM approach & Substrate \\
\hline $\begin{array}{l}\text { APTES (aminopropyltriethoxy silane) and NAATS (n- (2- } \\
\text { aminoethyl) - } 11 \text {-aminoundecyltrimethoxysilane }\end{array}$ & $\begin{array}{l}\text { Silicon and geranium (SiGe) } \\
\text { [32] }\end{array}$ \\
\hline Octadecane thiol (ODT) and mercapto acetic acid (MAA) & Copper and gold [33] \\
\hline $\begin{array}{l}\text { EDC 1-Ethyl-3-(3-dimethylaminopropyl)-carbodiimide ar } \\
\text { NHS ( } N \text {-hydroxysuccinimide) }\end{array}$ & $\mathrm{PtO}_{\mathrm{x}}[34][35]$ \\
\hline
\end{tabular}

\subsection{Synthesis of SAM}

SAM plays a role as the substrate with desired long chain of alkanethiols with different head group or in a form of mixture. Some long chain of SAM have been developed for bacteria detection like mercapto undecanoic acid MUA (carboxyl terminal), mercapto propanosulfonic acid (MPS) (sulphur terminal), MCH (6-mercapto-1-hexanol) (hydroxyl 
terminal), DTT (sulphur terminal), and 11-amino-1-undecanethiol hydrochloride (AUT) (amine terminal), 1-undecanethiol (UDT) (amine terminal) [28]-[32]. Some approaches were mixing SAM with linker like EDC, NHS, and BSA (bovine serum albumin) to improve the stability, activate terminal function, and cover unyielding area. In the last decade, mixed SAM were preferred then the single alkanethiols due to time saving factor in fabrication. Some researchers collaborated the single SAM like MUA/DTT, MUA/MCH), DTSP 3-dithiobis(sulfosuccinimidyl-propionate) (amine terminal), DTBA (carboxyl terminal), 16mercaptohexadecanoic acid (MHDA) (carboxyl terminal), Mercaptoacetic acid (MACA) (carboxyl terminal) [33]-[35].

SAM allow variation in synthesis desired organic and biocompatible layer. Terminal group of SAM will affect to physical quality of the layer, especially for the wettability. Faucheux et.al investigated different terminal group of SAM $\left(\mathrm{CH}_{3}, \mathrm{PEG}, \mathrm{NH}_{2}, \mathrm{COOH}\right.$ and $\mathrm{OH})$ on a gold substrate. The result showed that $\mathrm{CH}_{3}$ refers to hydrophobic $\left(\square_{\mathrm{a}}>80^{\circ}\right)$, while carboxyl and amine lead to wettable surface $\left(\square_{\mathrm{a}}=48-62^{\circ}\right)$, and ethylene glycol and hydroxyl correspondence to wettable substrata $\left(\square_{\mathrm{a}}<35^{\circ}\right)$. Dramatically, when the surface contained of polar and non-polar component, the polar compartment preferred to hydrophilic, in point if its concentration is low. Bain et.al measured water contact angle for different terminal function $\left(\mathrm{CH}_{3}\right.$ and $\left.\mathrm{OH}\right)$ of alkanethiols from different solvent. The result showed that alkanethiols with methyl lead to hydrophilic ( $\square_{\mathrm{a}}<90^{\circ}$ ) and hydroxyl terminal function referred to hydrophobic $\left(\square_{\mathrm{a}}>100^{\circ}\right)[29][36]$.

\subsection{Characterization of SAM}

Some methods can be used to characterize the quality of SAM on the surface. Atomic force microscopy (AFM) can be used to monitor roughness, Fourier transform infra-red (FTIR) to characterize the nature and formation, X-ray photoelectron spectroscopy (XPS) to know the hydroxylation and binding energy, and water contact angle to see wettability [37], [39]-[44].

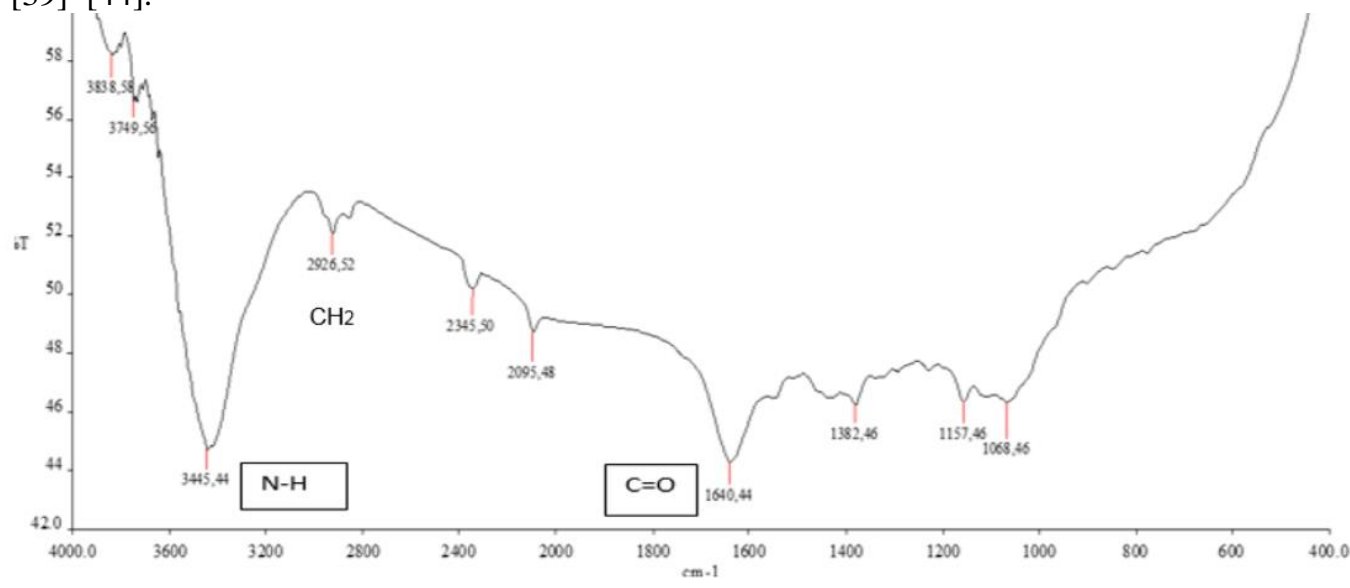

Fig. 4. $\mathrm{N}-\mathrm{H}, \mathrm{C}=\mathrm{O}$, and $\mathrm{CH} 2$ peaks in Fourier transform spectroscopy of SAM contains of $\mathrm{Au} / \mathrm{MUA} / \mathrm{EDC} / \mathrm{NHS}$ assembly [37]. 

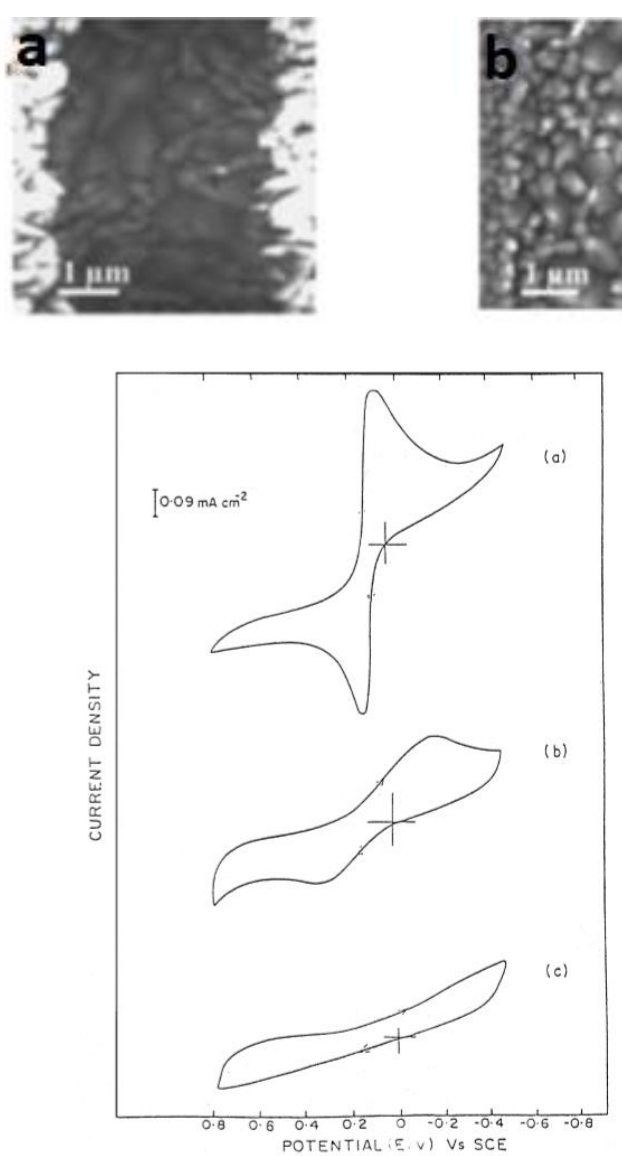

(B)

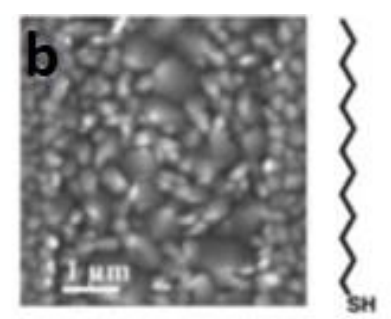

(A)

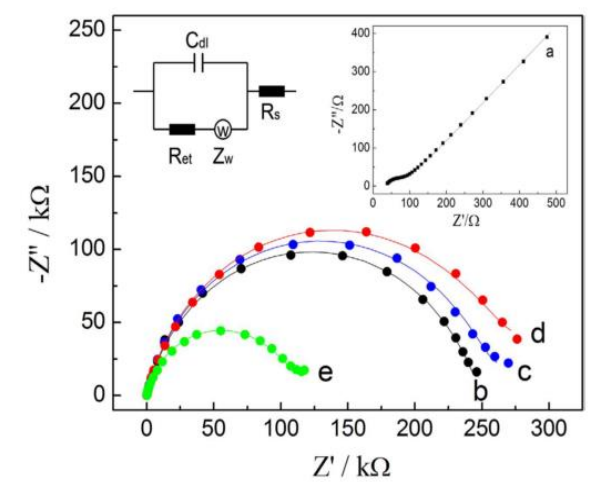

(C)

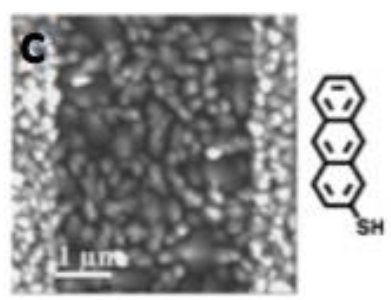

Fig. 5. (A) Surface roughness comparison of a) bare gold film, b) coated with alkanethiol, and c) tri hexane thiol [47], (B) Voltammogram comparison for a) a bar gold, b) gold coated naphthalene disulphide in 1-hour immersion, and c) 2-hours immersion [15], and (C) Nyquist plots of impedance spectra obtained for a) free bare gold electrode, b) gold electrode immersed with SAM MUA/UDT, c) antibody immobilization, d) E. coli conjugated, and e) gold electrode coated with E. coli [38].

. Singh et al characterized Au electrode coated MUA/EDC/NHS using FTIR and the result showed that $\mathrm{N}-\mathrm{H}, \mathrm{C}=\mathrm{O}$, and $\mathrm{CH} 2$ peak presents (Fig.4). Absolutely, it is confirmed mean that those three components of SAM are formed. However, Dibenedetto et al used AFM to characterize roughnesity of SAM formation. The difference could be viewed from the visualization, that free gold film is not fully compact grain surface than both Au/alkanethiol and $\mathrm{Au} /$ tri hexane thiol, and tri hexane thiol has more compact grain size than alkanethiol (Fig.5A). It has to show that SAM affect Au roughness due to its different roughness [45].

Electrical properties are also used to characterize SAM performance on an active surface substrate especially in biosensor application. Cyclic voltammetry is one of electrochemical technique to monitor the monolayer quality of biosensor. Sometime, some deposited monolayers are not fully cover the metal surface, some lack defects appear and this lack will inhibit contact between redox active molecule and the electrode. Here is the voltammogram comparison of the free bar of gold (a), gold coated naphthalene disulphide after immersion in 
1 hour (b) and 2 hours (c) using $\mathrm{K} 3 \mathrm{Fe}(\mathrm{CN}) 6$ in $0.1 \mathrm{M}$ aqueous $\mathrm{KCL}$ (Fig.5B). The redox activity showed decreasing at the time the monolayer become compact [15]. Nyquist plot impedance spectra is also part of electrochemical monitoring on a biosensor application. The formation of SAM 11-mercaptoundecanoic acid (MUA) and 1-undecanethiol (UDT) are proved by the shift of impedance value shown in figure 5C [38]

\section{Biosensor}

Biosensor is a detector device which functionalize biological reactions connected to a transducer. When biological component interacted with specific molecule target, a signal (analyte) is received by a transducer and produced detectable readout data, according to the concentration of the substance (Fig.6) [46]. Its broadly developed for cell detection, bacteria, molecule, and chemical component in food control, medical analysis and environment application [47].

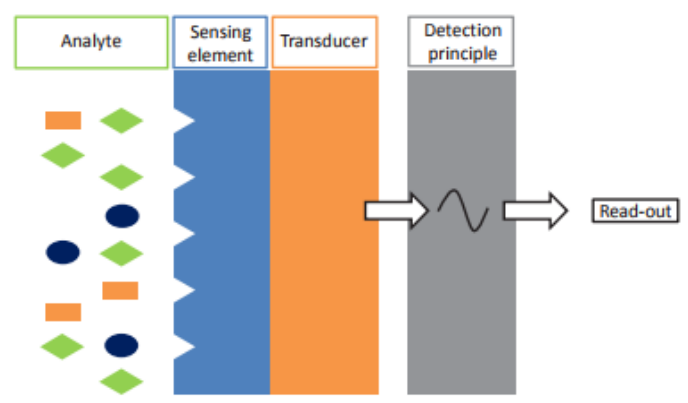

Fig. 6. Schematic diagram of biosensor working principle

Biosensor require to some main figures to achieve valid sensor. Some descriptions are mentioned below:

Table 2. Some required figures for a compact biosensor

\begin{tabular}{|c|c|}
\hline Figure & Definition \\
\hline Sensitivity & $\begin{array}{l}\text { An analytical system is sensitive. When } \\
\text { the concentration of analyte changes, } \\
\text { even though in a small change, by the } \\
\text { time it will response in a certain change }\end{array}$ \\
\hline Selectivity & $\begin{array}{l}\text { The system is selective. When the } \\
\text { analyte is differentiated, it will respond } \\
\text { in different responds }\end{array}$ \\
\hline Repeatable & $\begin{array}{l}\text { Closeness respond when system tested } \\
\text { in the same condition of operators, } \\
\text { laboratories, apparatus, and/or time } \\
\text { analysis interval }\end{array}$ \\
\hline $\begin{array}{l}\text { Limit of } \\
\text { detection }\end{array}$ & $\begin{array}{l}\text { Analytical system can detect the } \\
\text { smallest signal in a certain quantity with } \\
\text { an acceptable degree }\end{array}$ \\
\hline Reproducible & Closeness agreement when the system \\
\hline
\end{tabular}




\begin{tabular}{ll}
\hline & $\begin{array}{l}\text { built up in the same condition of } \\
\text { operators, laboratories, apparatus, and/or } \\
\text { time analysis interval }\end{array}$ \\
$\begin{array}{l}\text { Signal to } \\
\text { noise ratio }\end{array}$ & $\begin{array}{l}\text { Background noise of the analyte are } \\
\text { measured as a blank signal }\end{array}$ \\
\hline
\end{tabular}

Essentially, biosensor contains of a bio-receptor and a transducer [10]. It's known that biomolecule has specific interaction with another molecule, part of cell or chemical component. It can be functionalized become specific receptor to detect bio component or chemical detection. The potential biomolecule will be discussed later. Then these interactions will be detected by the transducers to produce a signal which can be measured by some mechanisms.

There are some developed transducers, like optical, piezoelectric, and electrochemical. Generally, optical mechanism is based on measuring the variation of refractive index or light emission/absorption, upon binding with the bacteria to be quantifiable data. While piezoelectric crystal's resonance oscillation frequency will reflect the mass change at the surface of sensor when bacteria and the receptor bond. Fundamentally, electrochemical produce an electrical charging between electrode and electrolyte of oxidation-reduction reaction (redox) when the receptor recognized the target [48].

\subsection{SAM and Biomolecules Attachment in E. coli Biosensor System}

Biomolecule is a promising selective agent one can functionalize. E. coli are categorized in negative bacteria in standard size $2-3 \mu \mathrm{m}$ which allow some component of their cell structure or lifecycle become a receptor agent in a biosensor [3] [10] . As negative gram bacterium, there are some components like polymer of sugar and peptide on the cell wall, namely lipopolysaccharides (LPS) (Fig.7A). LPS may bind to protein like lectin by lectin glucose interaction which can be hybridized from plant or animal [19]. On the other hand, antibody is specific recognition with antigen as specific and extensive glycoprotein either monoclonal or polyclonal which get involved in immune system (Fig.7B) [49][50].

Nucleic acid like DNA/RNA are another E. coli component that can be functionalized by hybridization for recognition component of biosensor. Generally, In order to produce protein, cells transcript the genes producing nucleic acid called mRNA, those are complementary with DNA (Fig.7C) [58]. Additionally, bacteriophages are also a promising receptor agent. It is generally known that phages are type of obligate viruses as parasites host specific onto bacteria for multiplication and propagation (Fig.7D). T2 and T4 phages are the examples of phage that lack specifically to E. coli [59] [60].

Their micro size allows to be miniaturized in biosensor system that need to be immobilized for easy fabricating, enhanced from any degradation, and tailored reusable material to lower the cost. However, an ordered SAM can be modified to attach with the biological components by covalent or non-covalent binding [61]. Covalent binding form amines group through formation of amide linkage or through cross linker binding and noncovalent binding with the head group of monolayer surfaces by hydrophobic, hydrophilic, and electrostatic interactions. Physical adsorption and bio affinity immobilization are also common techniques used [39]. The example is protein $A$ as a component of bacteria cell wall which can easily bond with the fc region (tail region) of antibody and streptavidin-biotin as protein and vitamin specific interaction which have the stable affinity even though in $\mathrm{pH}$ stress or temperature [43][62]. Generally, biosensor device transforms the signal produced by 
biomolecule-target binding into analytical. Basically, bacteria have a negative charge, while biomolecule binding have an affinity. These advantages unlocked the potential to be recognized by some detector to process the signal called transducer. Due to different signal recognition, some methods have been developed.

Table 3. SAM design approaches for E. coli detection

\begin{tabular}{|c|c|c|c|c|c|c|}
\hline SAM approach & $\begin{array}{c}\text { Head group/ } \\
\text { tail group }\end{array}$ & $\begin{array}{c}\text { Substr } \\
\text { ate }\end{array}$ & Linker & Bioreceptor & $\begin{array}{cc}\begin{array}{c}\text { Range } \\
\text { detection }\end{array} & \text { Transducer } \\
\end{array}$ & $\begin{array}{l}\text { Refer } \\
\text { ences }\end{array}$ \\
\hline $\begin{array}{l}16- \\
\text { mercaptohexadecanoi } \\
\text { c acid (MHDA) }\end{array}$ & $\mathrm{S} / \mathrm{COOH}$ & $\mathrm{Au}$ & $\begin{array}{c}\text { EDC/NHS } \\
\text { compared to } \\
\text { protein A }\end{array}$ & Antibody & $\begin{array}{l}10^{3}-10^{8} \text { Electrochemical } \\
\mathrm{CFU} / \mathrm{mL} \text { (Piezoelectric) }\end{array}$ & [51] \\
\hline $\begin{array}{l}\text { Polyethylene glycol } \\
\text { terminated } \\
\text { alkanethiol }\end{array}$ & $\mathrm{S} / \mathrm{OH}$ & $\mathrm{Au}$ & $\begin{array}{l}\text { EDC/NHS } \\
\text { compared to } \\
\text { protein } \mathrm{G}\end{array}$ & Antibody & $\begin{array}{l}10^{4}-10^{6} \quad \text { Optical (SPR) } \\
\mathrm{CFU} / \mathrm{mL}\end{array}$ & [52] \\
\hline $\begin{array}{l}\text { Mercaptoacetic acid } \\
\text { (MACA) }\end{array}$ & $\mathrm{S} / \mathrm{COOH}$ & $\mathrm{Au}$ & EDC/NHS & Antibody & $\begin{array}{cc}3 \times 10^{3}-3 & \text { Electrochemical } \\
10^{7} & \text { (EIS) } \\
\mathrm{CFU} / \mathrm{mL} & \end{array}$ & [53] \\
\hline $\begin{array}{l}\text { Mercaptoundecanoic } \\
\text { acid (MUA) and } \\
\text { dithiothreitol (DTT) }\end{array}$ & $\mathrm{S} / \mathrm{COOH}$ & $\mathrm{Au}$ & EDC/NHS & Lectin & $\begin{array}{l}10^{2}-10^{5} \text { Electrochemical } \\
\text { cells } / \mathrm{mL}\end{array}$ & [9] \\
\hline $\begin{array}{l}\text { 3-dithiobis- } \\
\text { (sulfosuccinimidyl- } \\
\text { propionate) (DTSP) }\end{array}$ & S/NHS & $\mathrm{Au}$ & Biotin-avidin & $\begin{array}{l}\text { Wheat germ } \\
\text { agglutinin }\end{array}$ & $\begin{array}{l}10^{2}-10^{7} \text { Electrochemical } \\
\mathrm{CFU} / \mathrm{mL} \quad \text { (EIS) }\end{array}$ & {$[6]$} \\
\hline $\begin{array}{l}11- \\
\text { mercaptoundecanoic } \\
\text { acid (MUA) and } \\
\text { 1-undecanethiol } \\
\text { (UDT) }\end{array}$ & $\mathrm{S} / \mathrm{COOH}$ & $\mathrm{Au}$ & EDC/NHS & Antibody & $\begin{array}{c}\text { - } \quad \text { Electrochemical } \\
\text { (EIS) }\end{array}$ & [38] \\
\hline $\begin{array}{l}\text { 11-amino-1- } \\
\text { undecanethiol } \\
\text { hydrochloride (AUT) }\end{array}$ & $\mathrm{S} / \mathrm{NH}$ & $\mathrm{Au}$ & $\begin{array}{c}\text { GNPs/CHIT- } \\
\text { MWNTs- } \\
\mathrm{SiO}_{2}-\mathrm{THI} \text { n }\end{array}$ & Antibody & $\begin{array}{l}4.12 \times 10^{2} \text {-Electrochemical } \\
4.12 \times 10^{5} \text { Amperometric) } \\
\text { CFU/mL }\end{array}$ & \\
\hline $\begin{array}{l}\text { mercaptohrxadecanoi } \\
\text { c acid (MHDA) }\end{array}$ & $\mathrm{S} / \mathrm{COOH}$ & $\mathrm{Au}$ & EDC/NHS & Antibody & $\begin{array}{lc}\text { Limit } & \text { Electrochemical } \\
\text { detection } & (\mathrm{QCM}) \\
2.0 \times 10^{2} & \\
\mathrm{CFU} / \mathrm{mL} & \\
\end{array}$ & [54] \\
\hline $\begin{array}{l}\text { Thiol terminated } \\
\text { oligoethylene glycol }\end{array}$ & $\begin{array}{c}\mathrm{S} /\left(\mathrm{OCH}_{2} \mathrm{CH}_{2}\right) \\
3 \mathrm{OH} \\
\end{array}$ & $\mathrm{Au}$ & - & $\alpha$-mannoside & $\begin{array}{l}10^{2}-10^{3} \text { Electrochemical } \\
\mathrm{CFU} / \mathrm{mL} \quad \text { (EIS) }\end{array}$ & {$[18]$} \\
\hline $\begin{array}{l}11- \\
\text { mercaptoundecanoic } \\
\text { acid (MUA) }\end{array}$ & $\mathrm{S} / \mathrm{COOH}$ & $\overline{\mathrm{Au}}$ & Protein $\mathrm{G}$ & Antibody & $\begin{array}{cc}10^{4} & \text { Optical (SPR) } \\
\text { cells } / \mathrm{mL}\end{array}$ & [55] \\
\hline $\begin{array}{l}11- \\
\text { mercaptoundecanoic } \\
\text { acid (MUA) }\end{array}$ & $\mathrm{S} / \mathrm{COOH}$ & $\mathrm{Au}$ & EDC/NHS & Phage & $\begin{array}{cc}10^{4} & \text { Electrochemical } \\
\mathrm{CFU} / \mathrm{mL} & \text { (EIS) }\end{array}$ & [37] \\
\hline $\begin{array}{l}\text { Biotinylated disulfide } \\
\text { monolayer, } \\
\text { biotinylated thiol }\end{array}$ & $\mathrm{S} / \mathrm{NH}$ & $\mathrm{Au}$ & Biotin-avidin & DNA & $\begin{array}{r}1000 \text { cells Electrochemical } \\
\text { (Amperometric }\end{array}$ & [56] \\
\hline
\end{tabular}




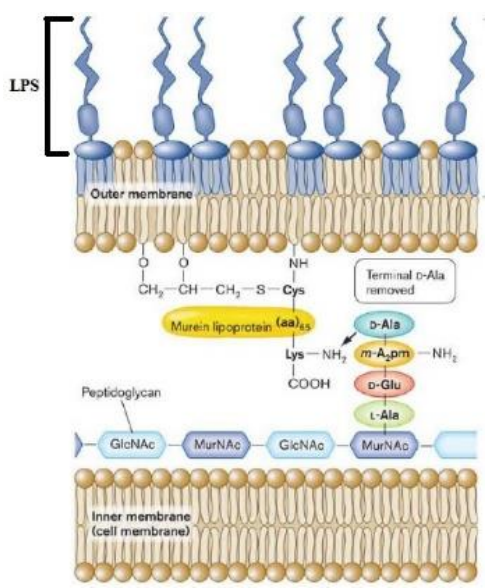

(A)

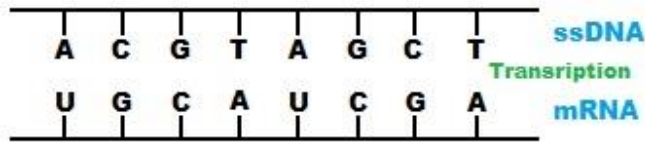

(C)

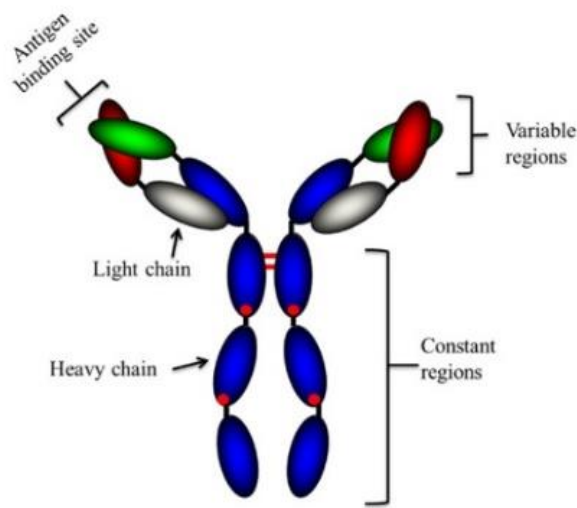

(B)

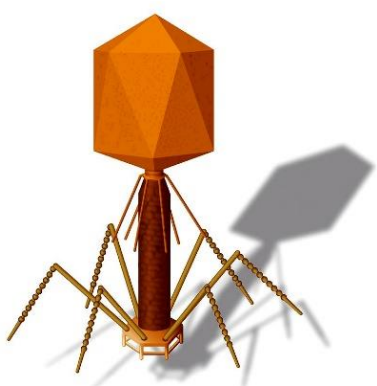

(D)

Fig. 7. (A) Outer cell wall of negative bacteria [20], (B) Antibody structure, (C) Base nitrogen complementary, and (D) Phage structure [50] [57].

Subramanian et.al immobilized antibody by covalent amide bonds on a mixed SAM hexaethylene glycol terminated thiol onto a sensor chip which were built on $50 \mathrm{~nm}$ gold with $\mathrm{S}$ bonding. The biosensor system is based on surface plasmon resonance, a reflection of light from thin metal film that will shift the reflectance index when any binding occurred on the sensor. Antibody were immobilized by physical adsorption the result showed that the reflectance indexed unit were dramatically increased in different concentration of antibody immobilization with SAM, 10, 20, and $30 \mu \mathrm{g} / \mathrm{ml}$ variation increase the RIU from 1960, 2361, and $2647 \mu$ RIU. The response of antibody and E. coli binding increase reflectance index followed by increasing the serial dilution of bacteria. However, this investigation is urgently developed because the bacteria checked were mixed with Staphylococcus enteridis that absolutely lead to be non-selective device [52].

Wang et.al functionalized lectin on the sensor chip using EDC to tailor carboxyl terminal layer, with NHS to activate the SAM (Fig.8A). Lectin were immobilized with amide covalent binding. The result showed that the limit detection could reach 3 x $103 \mathrm{CFU} / \mathrm{ml}$. This biosensor is also less selective affected of lectin generally bond with any carbohydrate. Lipopolysaccharides are negative gram bacteria component that allow another bacteria from E. coli can be detected [63].

Another SPR was also explored to detect E. coli selectivity and sensitivity by Keun and co-workers to detect E. coli selective and sensitively. A monoclonal antibody is immobilized 
using bio affinity of protein $\mathrm{G}$ on 11-mercaptoundecanoic acid by covalent amide binding (Fig.8B). The refractance index shifted since immobilizing the SAM, protein linker, antibody, and followed by E. coli serial dilution. This SPR could detect E. coli in limit detection 104 $\mathrm{CFU} / \mathrm{ml}$ compared with another bacteria like Salmonella, Shigella, Vibrio, and Yersinia [55].

However, electrochemical is also another approach explored for E. coli detection. They miniaturize the sensing electrode generally less expensive, less complicated and more sensitive. Electrochemical produce an electrical charging between electrode and electrolyte of oxidation-reduction reaction (redox) [64]. Mixed SAM MUA (mercaptoundecanoic acid) and EDC-NHS were used by Singh in immobilizing the isolated bacteriophage by covalent binding with NHS cross linked to gold scaffold (Fig.8C) [15]. As known that the electron properties connected from the basis substrate to the surface, when the bacteria attached the electron transfer are blocked, that can increase the impedance. This biosensor could detect E. coli in limit detection $104 \mathrm{CFU} / \mathrm{ml}$ [37].

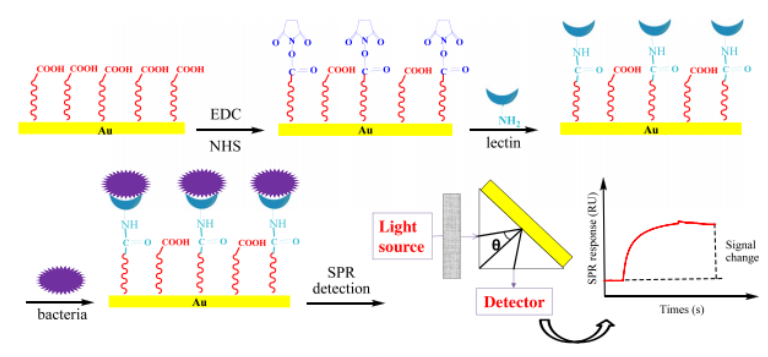

(A)

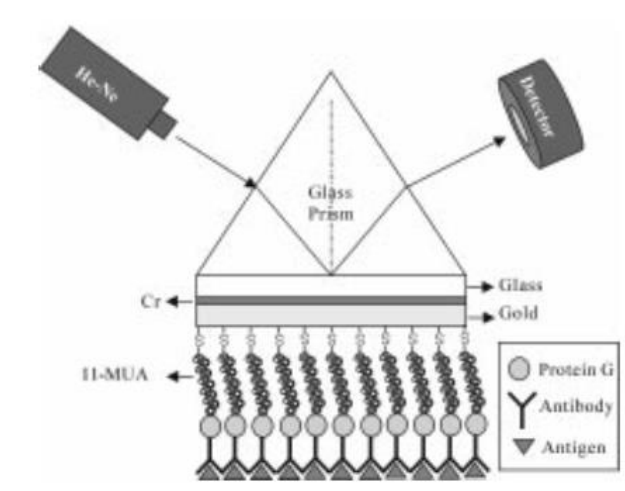

(B)
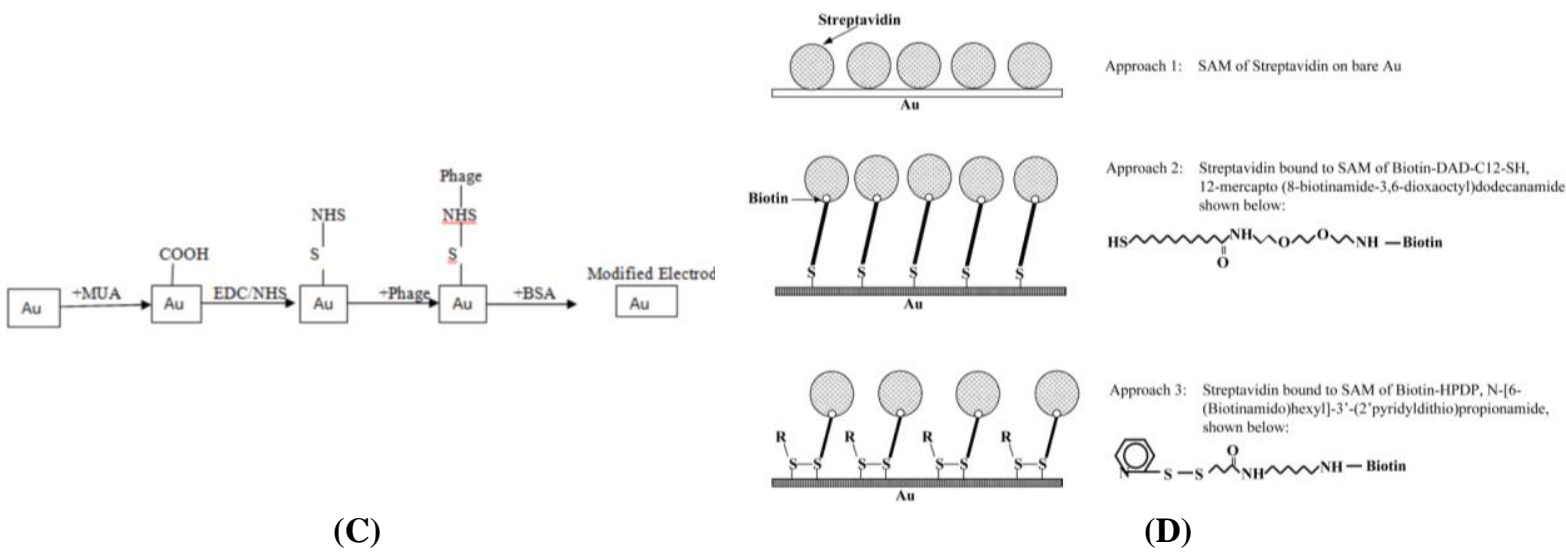

Fig. 8. (A) Sensor arrangement of Au/thiol/EDC-NHS and detection mechanism of surface plasmon resonance [67], (B) Sensor arrangement 11-MUA/protein G/antibody and the flow of SPR detection method [58], (C) Au/MUA/EDC-NHS/phage sensor arrangement schematic diagram [40], and (D) Comparison of streptavidin-biotin approach in different scaffold: bare gold, Au/thiol-biotinylated, and Au/disulphide-biotinylated [59] 


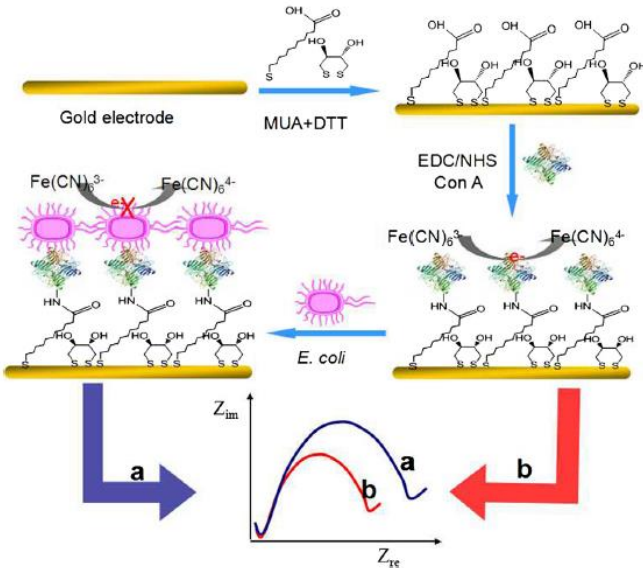

(A)

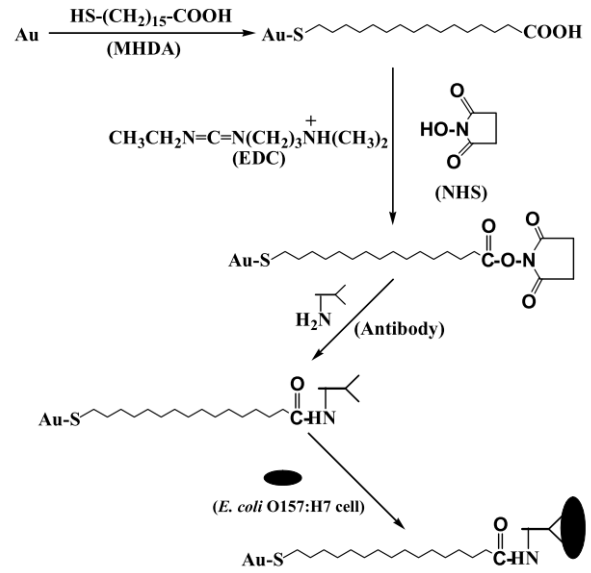

(C)

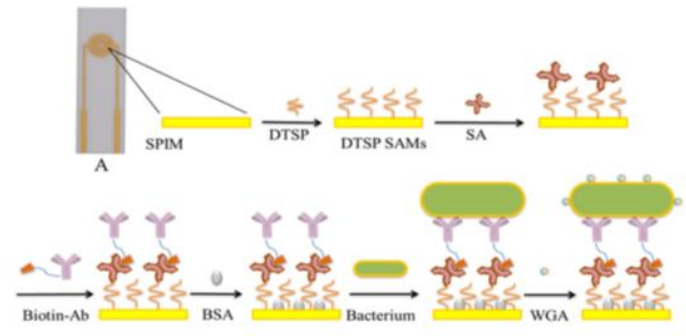

(B)

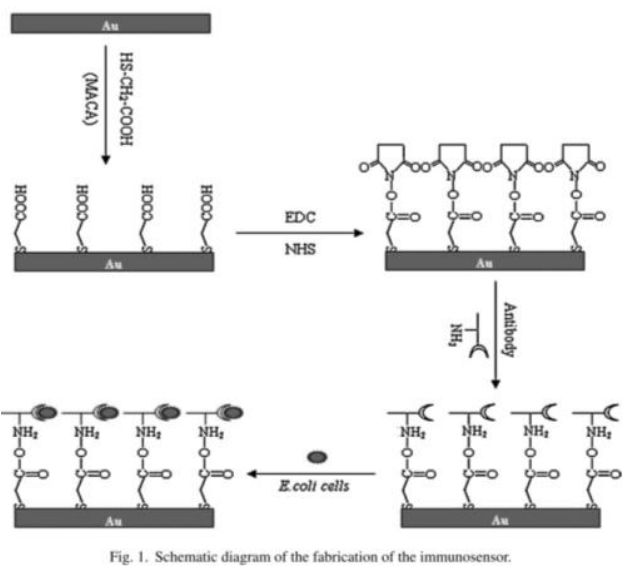

(D)

Fig. 9. (A) Schematic diagram of impedimetric sensor MUA/DTT/EDC-NHS/lectin-based biosensor for E. coli detection [9], (B) Sensor arrangement of DTSP/biotinavidin/antibody/BSA/WGA/bacteria attachment schematic diagram [6], Sensor reaction arrangement in bacterial detection schematic diagram (C) Au/MHDA/EDC-NHS/antibody

[54], and (D) Au/MACA/EDC-NHS/antibody [56].

Another biomolecule component used is oligonucleotide (ssDNA) which is reported by Gau et.al (Fig.8D). They investigated free biotin thiolated gold, biotin thiolated gold, and biotin disulphide gold. The result showed that biotin thiolated gold (12-mercapto (8biotinamide -3 , 6-dioxaoctyl) dodecanamide) $\sim 80 \%$ coverage with $\sim 3000$ RU SPR index compared to the free one that only covered $\sim 52 \%$ with $\sim 2400 \mathrm{RU}$, and biotinylated disulphide covered $\sim 10 \%$ with $\sim 1500 \mathrm{RU}$. Then followed by amperometric test with three electrodes in redox reaction till the potential occurred. However, the amperometric signal decreased followed by the number of serial dilutions of E. coli and Bordetella the lowest signal occurred showed as negative control. This E. coli biosensor could detect $103 \mathrm{CFU} / \mathrm{ml}$ in limit detection [56]. 
Lectin was also functionalized on the different mixed SAM. The combination was mercapto undecanoic acid (MUA) with every single MCH, MCE, and DTT (Fig.9A) MUA+DTT dramatically performed the optimize one than others in the value of electron transfer resistance when conjugated to mannan (monosaccharide). When the biosensor is tested using the E. coli sample, result showed that the limit detection reached $75 \mathrm{cell} / \mathrm{ml}$ [9].

Mixed SAM briefly explored today, preferred then single thiol with desired terminal function (Fig.9B). Li et.al investigated DTSP compared to MPA with common carboxyl activator EDC+NHS. The carboxyl terminal function of MPA had to be tailored with EDC, and then NHS just activated and resulting covalent amide bonds. It was the classic method that require extra time then. Antibody monoclonal was the biomolecule agent applied in different concentration to achieve the optimum one. Biosensor performed $102 \mathrm{CFU} / \mathrm{ml}$ in limit detection [6].

Another single thiol is 16-mercaptohexadecanoic acid (MHDA) and MACA (Mercaptoacetic acid). MHDA was developed for biocompatible scaffold for antibody immobilization. Alkanethiol with a long-chain carboxylic acid terminal form an ordered and oriented monolayer self-assembled onto Au (Fig.9C). A definitely aqueous solution succeeds to be formed in room temperature, and it was more stable than the short chain thiols or disulphide [51]. MACA is a short chain of alkanethiol with carboxylic acid terminal also (Fig.9D). Both MHDA and MACA were mixed with EDC-NHS not only to build amine linkage, but also could improve the stability of the linker compounds. MACA need to at least $60 \mathrm{~min}$ activation time while molecules immobilization with single thiol require many reactions that could not pack densely for steric hindrance [53]. MHDA approach showed better limit detection, with $10^{3}-10^{8} \mathrm{CFU} / \mathrm{ml}$ than MACA approach which was $3 \times 10^{3}-3 \times 10^{7}$ $\mathrm{CFU} / \mathrm{ml}$.

\subsection{SAM-Biosensor advantages and limitation}

SAM is being developed increasingly due to its advantages as an ordered platform to link the biomolecules either using some immobilization biomolecule or chemical linker or direct adsorption:

1. Stable platform and easy to form as an ordered free lack

2. SAM provide a scaffold like microenvironment cellular and it is necessary for immobilization of biomolecule.

3. Various head group can be flexibly designed to provide the suitable wettability both hydrophobic or hydrophilic.

4. The amount of biomolecule that will be immobilized on SAM substrate is in a minimum amount.

5. Stable and long-lasting storage which is reliable in several measurements

6. Allow for biological identification such as protein adsorption, antibody-antigen interaction, DNA hybridization etc using some sensitive equipment like AFM, FTIR, and SEM.

However, some cases limit SAM performance for biomolecule immobilization:

1. In case the composition of biomolecule is protein, an immobilized protein is susceptible being contaminated due to its sensitivity to the changes of $\mathrm{pH}$, temperature, and ionic strength: a few changes in it will affect to loss of the biological activity.

2. Oxidation can happen in sensitive chemical compounds of SAM approach during the formation, characterization, and the investigation.

3. The replaced electric field on a material by SAM adsorption and thermal desorption will 
decrease biosensor quality.

4. Through the hydrophobicity and high surface energy of SAM, it will block contaminant to contact within and accumulate the contaminants then block the recognition site of analyte.

Acknowledgment. Authors gratefully acknowledge financial support for this paper trough Trans-Disciplinary Research Grant scheme (TRGS) Vot T002 of Ministry of higher education (MOHE, Malaysia).

\section{References}

[1] W. A. Gerhard, W. S. Choi, K. M. Houck, and J. R. Stewart, "Water quality at points-of-use in the Galapagos Islands,” Int. J. Hyg. Environ. Health, vol. 220, no. 2, pp. 485-493, 2017.

[2] P. Cornelis, "Expressing genes in different Escherichia coli compartments," Curr. Opin. Biotechnol., no. 11, pp. 450-454, 2000.

[3] A. J. Stunkard, "A Brief Overview of Escherichia coli O157:H7 and Its Plasmid O157," Psychiatry Interpers. Biol. Process., vol. 162, no. 3, pp. 214-220, 2009.

[4] F. Addendum and T. O. Third, "Guidelines for Drinking-water Quality," vol. 1.

[5] L. Zheng, Y. Wan, P. Qi, Y. Sun, D. Zhang, and L. Yu, "Lectin functionalized ZnO nanoarrays as a 3D nano-biointerface for bacterial detection," vol. 167, no. December 2016, pp. 600-606, 2017.

[6] Z. Li, Y. Fu, W. Fang, and Y. Li, "Electrochemical Impedance Immunosensor Based on SelfAssembled Monolayers for Rapid Detection of Escherichia coli O157:H7 with Signal Amplification Using Lectin,” Sensors, vol. 15, no. 8, pp. 19212-19224, 2015.

[7] J. Ettenauer, K. Zuser, K. Kellner, T. Posnicek, and M. Brandl, "Development of an automated biosensor for rapid detection and quantification of E. coli in water," Procedia Eng., vol. 120, no. 0, pp. 376-379, 2015.

[8] H. Yang, H. Zhou, H. Hao, Q. Gong, and K. Nie, "Detection of Escherichia coli with a label-free impedimetric biosensor based on lectin functionalized mixed self-assembled monolayer," Sensors Actuators, B Chem., vol. 229, pp. 297-304, 2016.

[9] J. Amani, A. Ahmadpour, A. Ali, I. Fooladi, and S. Nazarian, "Original article Detection of E . coli O157 : H7 and Shigella dysenteriae toxins in clinical samples by PCR-ELISA," Infecctious Dis., vol. 9, no. 3, pp. 278-284, 2015.

[10] S. B. Murugaiyan, R. Ramasamy, N. Gopal, and V. Kuzhandaivelu, "Biosensors in clinical chemistry: An overview.," Adv. Biomed. Res., vol. 3, p. 67, 2014.

[11] D. Morrison, K. Suh, and A. Khademhosseini, Micro and nanopatterning for bacteria-and virusbased biosensing applications. 2008.

[12] G. M. W. John P. Folkers, Paul E. Laibinis, "SAM of alkanethiols on gold comparisons of monolayers containing mixtures of short and long chain constituent with $\mathrm{CH} 3$ and $\mathrm{CH} 2 \mathrm{OH}$ terminal groups.pdf,” Langmuir Artic., vol. 8, no. 5, pp. 1330-1341, 1992.

[13] G. Heimel, L. Romaner, and E. Zojer, "A theoretical view on self-assembled monolayers in organic electronic devices,” Org. Optoelectron. Photonics, vol. 6999, pp. 1-12, 2008.

[14] G. K. Jennings and P. E. Laibinis, "Self-assembled monolayers of alkanethiols on copper provide corrosion resistance in aqueous environments," Colloids Surfaces A Physicochem. Eng. Asp., vol. $116,1996$.

[15] A. A. De Araujo, S. Roussos, and A. A. De Araújo, "Self-assembled monolayers as a tunable platform for biosensor applications," Appl. Biochem. Biotechnol., vol. 98-100, no. 1-9, pp. 311-318, 2002.

[16] C. M. Whelan, M. Kinsella, L. Carbonell, and H. M. Ho, "C orrosion inhibition by selfassembled monolayers for enhanced wire bonding on Cu surfaces," Microelectron. Eng., vol. 70, pp. 551-557, 2003.

[17] D. A. Hutt and C. Liu, "Oxidation protection of copper surfaces using self-assembled monolayers of octadecanethiol,” Appl. Surf. Sci., vol. 252, pp. 400-411, 2005. 
[18] X. Guo, A. Kulkarni, A. Doepke, H. B. Halsall, S. Iyer, and W. R. Heineman, "CarbohydrateBased Label-Free Detection of Escherichia coli ORN 178 Using Electrochemical Impedance Spectroscopy," Anal. Chem., pp. 241-246, 2012.

[19] K. P. Talaro and A. Talaro, Foundations in Microbiology. 2002.

[20] R. E. Reyes, C. R. González, R. C. Jiménez, M. O. Herrera, and A. A. Andrade, "Mechanisms of O-Antigen Structural Variation of Bacterial Lipopolysaccharide ( LPS ),” 2012.

[21] A. R. Melton-Celsa, "Shiga Toxin (Stx) Classification, Structure, and Function," Microbiol. Spectr., vol. 2, no. 4, pp. 1-21, 2014.

[22] M. A. Croxen, R. J. Law, R. Scholz, K. M. Keeney, M. Wlodarska, and B. B. Finlay, "Recent advances in understanding enteric pathogenic Escherichia coli," Clin. Microbiol. Rev., vol. 26, no. 4, pp. 822-880, 2013.

[23] F. Durmaz, "A Modular Approach to Functional Self-Assembled Monolayers," SWISS FEDERAL INSTITUTE OF TECHNOLOGY ZURICH, 2006.

[24] J. C. Love, L. a. Estroff, J. K. Kriebel, R. G. Nuzzo, and G. M. Whitesides, Self-Assembled Monolayers of Thiolates on Methals as a Form of Nanotechnology, vol. 105. 2005.

[25] G. Maduraiveeran and W. Jin, "Nanomaterials based electrochemical sensor and biosensor platforms for environmental applications," Trends Environ. Anal. Chem., vol. 13, pp. 10-23, 2017.

[26] C. E. D. C. Marc D. Porter, Thomas B. Bright, David L. Allara, "Spontaneously Organized Molecular Assemblies. 4. Structural Characterization of n-alkyl Thiol Monolayers on Gold by Optical Ellipsometry, Infrared Spectroscopy, and Electrochemistry,” J. Am. Chem. Sicoety, vol. 109, pp. 3359-3568, 1987.

[27] F. Mastrangelo, "Self-Assembled Monolayers (SAMs): Which Perspectives in Implant Dentistry?,” J. Biomater. Nanobiotechnol., vol. 02, no. 05, pp. 533-543, 2011.

[28] P.E Liabinis, -G.M. Whitesides, -D.L. Allara, -Y.T. Tao, -A.T. Parikh, and -R.G. Nuzzo, "Comparison of the structures and wetting properties of self-assembled monolayers of n-alkanethiols on the coinage metal surfaces, copper, silver, and gold," J. Am. Chem. Soc., vol. 113, pp. 7152-7167, 1991.

[29] N. L. Jeon, R. G. Nuzzo, Y. Xia, M. Mrksich, and G. M. Whitesides, "Patterned self-assembled monolayers formed by microcontact printing direct selective metalization by chemical vapor deposition on planar and nonplanar substrates," Langmuir, vol. 11, no. 8, pp. 3024-3026, 1995.

[30] R. I. Carey, J. P. Folkers, and G. M. Whitesides, "Self-Assembled Monolayers Containing omega Mercaptoalkylboronic Acids Adsorbed onto Gold Form a Highly Cross-Linked, Thermally Stable Borate Glass Surface,” Langmuir Artic., vol. 10, no. 7, pp. 2228-2234, 1994.

[31] C. D. Bain, J. Evall, and G. M. Whitesides, "Formation of Monolayers by the Coadsorption of Thiols on Gold: Variation in the Head Group, Tail Group , and Solventr," J. Am. Chem. Siociety, vol. 111, no. 18, pp. 7155-7164, 1989.

[32] S. Ebrahim, M. Raoof, W. Ramadan, and M. Soliman, "New self assembly monolayer onto SiGe as a selective biosensor for single-strand DNA," Microelectron. Eng., vol. 160, pp. 87-93, 2016.

[33] S. Varatharajan, S. Berchmans, and V. Yegnaraman, "Tailoring self-assembled monolayers at the electrochemical interface,” J. Chem. Sci., vol. 121, no. 5, pp. 665-674, 2009.

[34] S. Kumar, W. Ahlawat, R. Kumar, and N. Dilbaghi, "Graphene, carbon nanotubes, zinc oxide and gold as elite nanomater- ials for fabrication of biosensors for healthcare," Biosens. Bioelectron., vol. 70, pp. 498-503, 2015.

[35] J. M. Alonso, A. A. M. Bielen, W. Olthuis, S. W. M. Kengen, H. Zuilhof, and M. C. R. Franssen, "Self-assembled monolayers of 1-alkenes on oxidized platinum surfaces as platforms for immobilized enzymes for biosensing,” Appl. Surf. Sci., vol. 383, pp. 283-293, Oct. 2016.

[36] F. Xi, J. Gao, J. Wang, and Z. Wang, "Discrimination and detection of bacteria with a label-free impedimetric biosensor based on self-assembled lectin monolayer," Electroanal. Chem., vol. 656, pp. 252-257, 2011.

[37] V. Singh, P. Jain, and S. Dahiya, "Bacteriophage based self-assembled monolayer ( SAM ) on gold surface used for detection of Escherichia coli by electrochemical analysis," African J. Microbiol. Res., vol. 9, no. 30, pp. 1832-1839, 2015. 
[38] J. Wan, J. Ai, Y. Zhang, X. Geng, Q. Gao, and Z. Cheng, "Signal-off impedimetric immunosensor for the detection of Escherichia coli O157:H7," Sci. Rep., vol. 6, pp. 2-7, 2016.

[39] R. A. Taheri, A. H. Rezayan, F. Rahimi, J. Mohammadnejad, and M. Kamali, "Comparison of antibody immobilization strategies in detection of Vibrio cholerae by surface plasmon resonance," Biointerphases, vol. 11, no. 4, 2016.

[40] Y. Li et al., "Amperometric immunosensor for the detection of Escherichia coli O157:H7 in food specimens," Anal. Biochem., vol. 421, no. 1, pp. 227-233, 2012.

[41] A. H. Schmid, S. E. Stanca, M. S. Thakur, K. R. Thampi, and C. R. Suri, "Site-directed antibody immobilization on gold substrate for surface plasmon resonance sensors," Sensors Actuators, B Chem., vol. 113, no. 1, pp. 297-303, 2006.

[42] Ó. A. Loaiza, S. Campuzano, M. Pedrero, and J. M. Pingarrón, "DNA sensor based on an Escherichia coli lac $\mathrm{Z}$ gene probe immobilization at self-assembled monolayers-modified gold electrodes," Talanta, vol. 73, no. 5, pp. 838-844, 2007.

[43] L. S. Jang and H. K. Keng, "Modified fabrication process of protein chips using a short-chain self-assembled monolayer," Biomed. Microdevices, vol. 10, no. 2, pp. 203-211, 2008.

[44] M. Retsch, A. Walther, K. Loos, and A. H. E. Müller, "Synthesis of dense poly(acrylic acid) brushes and their interaction with amine-functional silsesquioxane nanoparticles," Langmuir, vol. 24 , no. 17, pp. 9421-9429, 2008.

[45] B. S. A. Dibenedetto, A. Facchetti, M. A. Ratner, and T. J. Marks, "Molecular Self-Assembled Monolayers and Multilayers for Organic and Unconventional Inorganic Thin-Film Transistor Applications," Adv. Mater., vol. 21, pp. 1407-1433, 2009.

[46] P. S. Andrea, BIOSENSORS. 2010

[47] C. I. L. Justino, A. C. Duarte, and T. A. P. Rocha-Santos, "Critical overview on the application of sensors and biosensors for clinical analysis," Trends Anal. Chem. Anal. Chem., vol. 85, pp. 36-60, 2016.

[48] J. T. Brooks et al., "Non-O157 Shiga toxin-producing Escherichia coli infections in the United States," J. Infect. Dis., vol. 192, no. September, pp. 1422-1429, 2005.

[49] J. Slonczewski, Joan and Foster, Microbiology an Evolving Science. 2011.

[50] S. Sharma, H. Byrne, and R. J. O. Kennedy, "Antibodies and antibody-derived analytical biosensors," Essays Biochem., vol. 60, no. June, pp. 9-18, 2016.

[51] X. L. Su and Y. Li, "A self-assembled monolayer-based piezoelectric immunosensor for rapid detection of Escherichia coli O157:H7," Biosens. Bioelectron., vol. 19, no. 6, pp. 563-574, 2004.

[52] A. Subramanian, J. Irudayaraj, and T. Ryan, "A mixed self-assembled monolayer-based surface plasmon immunosensor for detection of E. coli O157:H7," Biosens. Bioelectron., vol. 21, no. 7, pp. 998-1006, 2006.

[53] P. Geng et al., "Self-assembled monolayers-based immunosensor for detection of Escherichia coli using electrochemical impedance spectroscopy," Electrochim. Acta, vol. 53, no. 14, pp. 46634668, 2008.

[54] L. Wang, C. Wu, Z. Hu, Y. Zhang, R. Li, and P. Wang, "Sensing Escherichia coli O157:H7 via frequency shift through a self-assembled monolayer based QCM immunosensor," Anal. Chem., vol. 9 , no. 2, pp. 121-131, 2008.

[55] Y. Kim, Y. M. I. N. Bae, and W. O. N. H. Lee, "Detection of Escherichia coli O157 : H7 Using Immunosensor Based on Surface Plasmon Resonance," J. Microbiol. Biotechnol., vol. 12, no. 5, pp. 780-786, 2002.

[56] J. Gau, E. H. Lan, B. Dunn, C. Ho, and J. C. S. Woo, "A MEMS based amperometric detector for E . Coli bacteria using,” Biosens. Bioelectron., vol. 16, pp. 745-755, 2001.

[57] L. Gervais et al., "Immobilization of biotinylated bacteriophages on biosensor surfaces," Sensors Actuators, B Chem., vol. 125, no. 2, pp. 615-621, 2007.

[58] D. Ivnitski, I. Abdel-hamid, P. Atanasov, E. Wilkins, and S. Stricker, "Application of Electrochemical Biosensors for Detection of Food Pathogenic Bacteria," Electroanalysis, vol. 12, no. 5, pp. 317-325, 2000.

[59] C. Halford, V. Gau, B. M. Churchill, and D. A. Haake, "Bacterial Detection \& Identification Using Electrochemical Sensors," J. Vis. Exp., no. April, pp. 1-8, 2013. 
[60] F. P. Detection, "Recent Advances in Bacteriophage Based Biosensors for Food-Borne Pathogen Detection," Sensors, vol. 13, pp. 1763-1786, 2013.

[61] Y. Zhou, C. W. Chiu, and H. Liang, "Interfacial structures and properties of organic materials for biosensors: An overview," Sensors, vol. 12, no. 11, pp. 15036-15062, 2012.

[62] E. P. Diamandis and T. K. Christopoulos, "the Biotin (Strept)Avidin System - Principles and Applications in Biotechnology," Clinical Chemistry, vol. 37, no. 5. pp. 625-636, 1991.

[63] Y. Wang, Z. Ye, C. Si, and Y. Ying, "Monitoring of Escherichia coli O157 : H7 in food samples using lectin based surface plasmon resonance biosensor," J. Food Chem., vol. 136, pp. 1303-1308, 2013.

[64] W. Dou, W. Tang, and G. Zhao, "A disposable electrochemical immunosensor arrays using 4channel screen-printed carbon electrode for simultaneous detection of Escherichia coli O157 : H7 and Enterobacter sakazakii," Electrochim. Acta, vol. 97, pp. 79-85, 2013. 